\title{
EVALUATION OF MAGNETIC CARRIERS EMPLOYED FOR IMMOBILIZATION OF LIPASE FROM CANDIDA RUGOSA
}

\section{AVALIAÇÃO DE SUPORTES MAGNÉTICOS UTILIZADOS PARA IMOBILIZAÇÃO DA LIPASE DE CANDIDA RUGOSA}

\section{O. DOMINGUES ${ }^{1, *}$, L. K. SANTOS ${ }^{2}$, R. D. HERCULANO ${ }^{1}$, D. L. FLUMIGNAN ${ }^{2,3}$ and A. V. PAULA ${ }^{1}$}

${ }^{1}$ Department of Engineering Bioprocesses and Biotechnology, School of Pharmaceutical Sciences, São Paulo State University (UNESP), Araraquara, São Paulo, Brazil.

${ }^{2}$ Department of Organic Chemistry, Institute of Chemistry, São Paulo State University (UNESP), Araraquara, São Paulo, Brazil.

${ }^{3}$ Campus Cuiabá, Mato Grosso Federal Institute of Education, Science and Technology (IFMT), Cuiabá, Mato Grosso, Brazil.

${ }^{*}$ Corresponding author. Department of Engineering Bioprocesses and Biotechnology, School of Pharmaceutical Sciences, São Paulo State University (UNESP),

Araraquara, São Paulo, Brazil, Phone: +5516993338879

e-mail address: otavio_domingues2013@hotmail.com (O. Domingues).

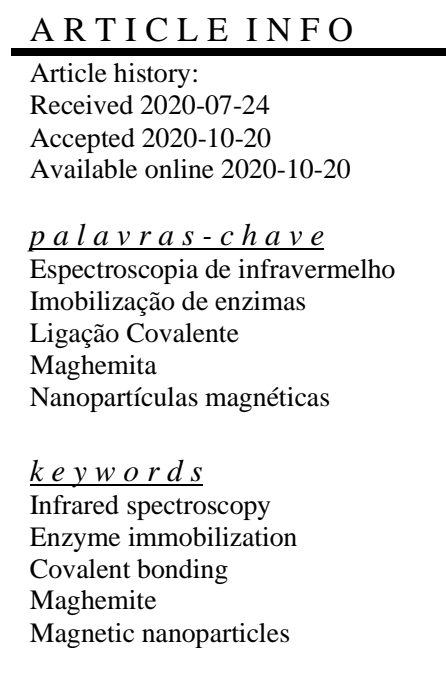

\begin{abstract}
A B S T R A C T
Currently, the use of magnetic nanoparticles has aroused interest in industrial processes, and the combination of their properties with the immobilization of lipases has been developed in order to produce carriers of easy separation of the reaction medium. In this context, the objective of the present study was to immobilize Candida rugosa lipase in magnetic nanoparticles, such as magnetite and maghemite, by physical adsorption and covalent bonding. The biocatalysts were evaluated by infrared spectroscopy (FTIR) and hydrolytic activity analysis. Thus, from the analyses performed, the best biocatalyst obtained was the immobilized by covalent bond in maghemite, presenting a hydrolytic activity of $174.67 \mathrm{U} / \mathrm{g}$.
\end{abstract}

R E S U M O

Atualmente, o uso de nanopartículas magnéticas tem despertado interesse em processos industriais, e a combinação de suas propriedades com a imobilização de lipases tem sido desenvolvida a fim de produzir suportes de fácil separação do meio reacional. Nesse contexto, o objetivo do presente estudo foi imobilizar a lipase de Candida rugosa em nanopartículas magnéticas, como magnetita e maghemita, por adsorção física e ligação covalente. Os biocatalisadores foram avaliados por espectroscopia de infravermelho (FTIR) e análise de atividade hidrolítica. Dessa forma, a partir das análises realizadas, o melhor biocatalisador obtido foi o imobilizado por ligação covalente em maghemita, apresentando atividade hidrolítica de 174,67 U/g. 
In the study were used: Candida rugosa lipase (CRL); maghemite $(\mathrm{MH})$, magnetite synthesized using sodium hydroxide (MN1) and ammonium hydroxide (MN2), in addition to immobilized biocatalysts by physical adsorption (A): lipase immobilized in maghemite (MH-A-CRL) and magnetite (MN1A-CRL and MN2-A-CRL); and covalent bonding (C): immobilized in maghemite (MH-C-CRL) and magnetite (MN1C-CRL and MN2-C-CRL).

\section{INTRODUCTION}

In the current industrial context, the search for ways of reusing biocatalyst has gained ample space among research to improve and reduce costs in biotechnological processes, such as the use of enzymes. These are protein polymers formed by peptide bonds between two adjacent amino acids, presenting a three-dimensional region formed by amino acid residues (CAMPESTRINI et al., 2005). Among the enzymes, lipases stand out for its ability to perform hydrolysis of long-chain triglycerides, whose industrial applications range from use in the food industry to obtaining bioactive molecules (REZANKA et al., 2017). In addition, the use of this biocatalyst is more ecological due to the lower production of toxic agents and byproducts (ZHENG et al., 2017). Among the lipases from several microorganisms, the biocatalyst used in the study was Candida rugosa lipase (CRL).

Considering the high added value and the advantages of the use of lipases, immobilization is an alternative for its reuse, influencing and modifying parameters such as stability after immobilized, and can be performed by different methodologies (CARVALHO et al., 2015). Adherence by physical adsorption is based on the interaction of the enzyme with the carrier used. This interaction occurs through weak forces such as hydrophobic, ionic, hydrogen bonds and Van der Waals forces. However, this method is advantageous due to its easy execution, having as a disadvantage the high chance of desorption due to the weak interaction of the derivative with the support used. (SHELDON; PELT, 2013).

Immobilization by covalent bonding occurs due to the strong chemical bond between enzyme and support. In this methodology, the carrier should be modified with some functionalizing agent in order to facilitate that regions of the enzyme bind covalently. A positive outlook for this immobilization methodology is the irreversible characteristic of the binding formed by the enzyme and the support, avoiding the desorption that occurred when immobilized by physical adsorption (TAN et al., 2010). However, because it is a chemical bond, there may be a decrease in the biological activity of the enzyme due to a possible impediment of the active site with immobilization (BRÍGIDA, 2010). For the use of a material as a carrier for immobilization, the contact surface, ions, solubility, mechanical strength, and biocatalyst, being classified according to its composition, inorganic and organic, and morphological structure, in non-porous, porous and gel structure (CARVALHO et al., 2015).

Therefore, due to the search for improvements in biotechnological processes and the use of new supports for immobilization of enzymes, magnetic supports draw attention due to advantages such as resistance to high temperatures, mass transfer and the available surface for immobilization (PINTO, 2017). In this study, the carriers used for immobilization were maghemite $\left(\gamma \mathrm{Fe}_{2} \mathrm{O}_{3}\right)$ and magnetite $\left(\mathrm{Fe}_{3} \mathrm{O}_{4}\right)$ and the crystalline structure of each of the nanoparticles is shown in Figures 1 and 2.

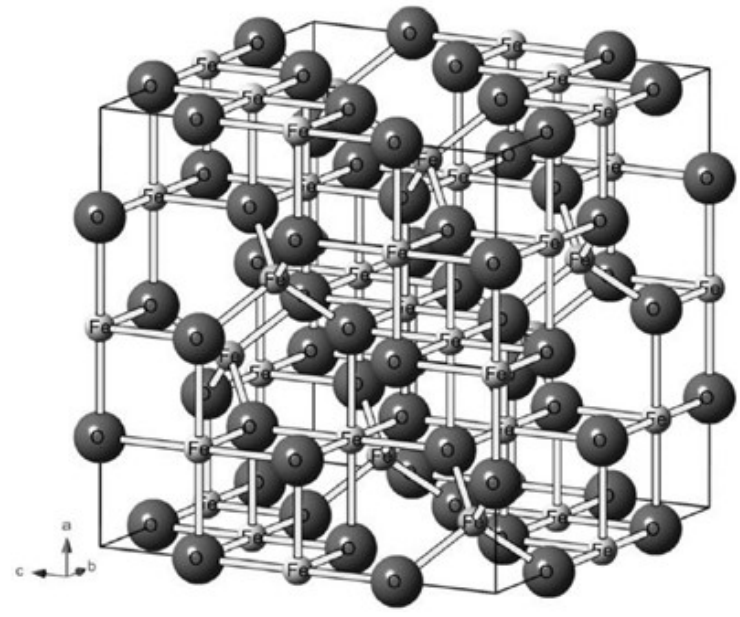

Figure 1. Maghemite crystalline structure. Source: Oliveira et al. (2013).

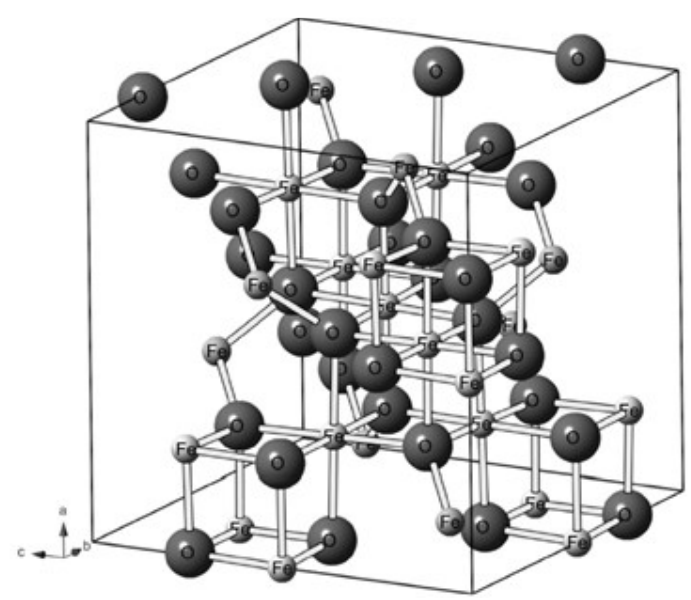

Figure 2. Magnetite crystalline structure. Source: Oliveira et al. (2013).

Magnetite nanoparticles are iron oxides formed by a structure composed of oxygen ions, whose interstitial spaces are filled with ferrous iron ions $\left(\mathrm{Fe}^{2+}\right)$, ferric iron ions $\left(\mathrm{Fe}^{3+}\right)$, differing by the absence of ferrous iron for maghemite synthesis (DUNLOP and ÖZDEMIR, 1997). Moreover, the main justification for the use of magnetic materials is the easy removal of the immobilized derivative with a magnetic field after the process (PINTO, 2017). 


\section{MATERIAL E METHODS}

\subsection{Maghemite Synthesis}

The synthesis followed modified methodology of Junior et al. (2010), adding $30 \mathrm{~mL}$ of ultra-pure water and $20 \mathrm{~mL}$ of $\mathrm{Na}_{2} \mathrm{SO}_{3}$ solution $(1 \mathrm{M})$, in this order, in $30 \mathrm{~mL}$ of $\mathrm{FeCl}_{3} \cdot 6 \mathrm{H}_{2} \mathrm{O}$ solution ( $2 \mathrm{M}$, prepared in $\mathrm{HCl} 2 \mathrm{M}$ ), under agitation until the solution turned yellow. $51 \mathrm{~mL}$ ammonium hydroxide $(25 \%)$ were added in $870 \mathrm{~mL}$ of ultra-pure water, followed by the addition of the previously obtained yellow solution, maintaining at $3000 \mathrm{rpm}$ for 1 hour. At the end, the dark mass obtained was washed with ultra-pure water and dried at $100^{\circ} \mathrm{C}$ for $24 \mathrm{~h}$. The dried mass was taken to laboratory muffle at $250^{\circ} \mathrm{C}$ for $1 \mathrm{~h}$. the synthesis yield (Y) was calculated according to Equation 1.

$Y(\%)=\frac{m(M H)}{M_{T}} * 100$

where $\mathrm{m}(\mathrm{MH})$ is the mass of maghemite obtained in the synthesis and $\mathrm{M}_{\mathrm{T}}$ is the total mass of $\mathrm{FeCl}_{3}$ used.

\subsection{Magnetite Synthesis}

The synthesis was carried according to the coprecipitation methodology of $\mathrm{Fe}^{2+}$ and $\mathrm{Fe}^{3+}$, proposed by Mijone (2014), using $30 \mathrm{~mL}$ of $\mathrm{FeCl}_{2}$ solution $(0.6 \mathrm{M})$ and $300 \mathrm{~mL}$ of ultra-pure water under high agitation, followed by the addition of $30 \mathrm{~mL}$ of $\mathrm{FeCl}_{3} .6 \mathrm{H}_{2} \mathrm{O}$ solution $(1.1 \mathrm{M})$, maintained at $80^{\circ} \mathrm{C}$. Then, was adjusted $\mathrm{pH} 11$ adding solution (4 M) of precipitating agents (sodium hydroxide and ammonium hydroxide, independent and separate processes). After $30 \mathrm{~min}$, the container was kept under a magnet and the recovered mass was washed with ethyl acetate and ultra-pure water $(1: 1)$, dried at $100^{\circ} \mathrm{C}$ for $24 \mathrm{~h}$. The yield was calculated according to Eq. 1, and the $\mathrm{M}_{\mathrm{T}}$ value corresponding to the mass of $\mathrm{FeCl}_{2}$ and $\mathrm{FeCl}_{3}$ used in the synthesis

\subsection{Surface Modification of Nanoparticles}

For immobilization by covalent bond, a step of modification of the nanoparticles was necessary, and the activation process with APTES (3- aminopropyltrithoxysilane) proposed by Kumar et al. (2013) and the process of functionalization with glutaraldehyde described by Vescovi et al. (2016). For activation, the nanoparticles were dried at $200^{\circ} \mathrm{C}$ for $2 \mathrm{~h}$ and then added $500 \mathrm{mg}$ in a solution prepared with 20 mL heptane and $240 \mu \mathrm{L}$ APTES (3- aminopropylthetoxysilane). The mixture was kept in an atmosphere of $\mathrm{N}_{2}$ at $75^{\circ} \mathrm{C}$ for $3 \mathrm{~h}$. The obtained solid was washed with hexane and stored for lipase immobilization. The activated nanoparticles were functionalized by adding phosphate buffer solution $\mathrm{pH} 7.4$ (0.1 $\mathrm{M})$, ratio $1: 18(\mathrm{~m} / \mathrm{v})$, adding $2 \mathrm{~mL}$ of glutaraldehyde $(25 \%)$ for each $1 \mathrm{~g}$ of support. The mixture was kept under agitation at room temperature for $3 \mathrm{~h}$, followed by $1 \mathrm{~h}$ at rest at the end of the process. The mass obtained was washed with alcohol, water and buffer solution and maintained at $4^{\circ} \mathrm{C}$ until immobilization.

\subsection{Immobilization of CRL}

The immobilization process of Candida rugosa lipase (L1754, EC. 3.1.1.3, type VII and protein content of $16 \% \mathrm{~m} / \mathrm{m}$ ) was carried using the unmodified nanoparticles (immobilization by physical adsorption) and modified nanoparticles (covalent bonding), according to modified methodology by Paula (2012). The nanoparticles were immersed in phosphate buffer solution pH $5(0.1 \mathrm{M})$, in a ratio $1: 10(\mathrm{~m} / \mathrm{v})$, maintained at room temperature for $2 \mathrm{~h}$. Then, for each $1 \mathrm{~g}$ of support, $200 \mu \mathrm{L}$ of PEG 1500 solution $(0.5 \mathrm{mg} / \mathrm{mL})$ and $0.25 \mathrm{~g}$ of lipase were added, remaining under agitation at $8^{\circ} \mathrm{C}$ for $24 \mathrm{~h}$. The biocatalyst was washed with buffer solution and kept in desseccator until use.

\subsection{Physical Characterization}

In order to analyze the processes of modification and immobilization, infrared spectroscopy (FTIR) was performed, using the PLATINUM-ATR infrared spectrometer (Bruker). The graphs were plotted using ORIGIN 8.0 software.

\subsection{Determination of Hydrolytic Activity (A)}

The activity was determined using Spanish Extra Virgin Olive Oil CARBONELL and phosphate buffer pH 7 (0.1 M), according to the modified methodology described by Paula (2012). Thus, $4.5 \mathrm{~mL}$ of olive oil emulsion, olive oil:water: phosphate buffer (5:5:8) were added in an Erlenmeyer and left at $37^{\circ} \mathrm{C}$ in thermostatized bath (Dubnoff) for $10 \mathrm{~min}$. Then, 50 $\mathrm{mg}$ of biocatalyst was added and the same temperature in constant agitation for $5 \mathrm{~min}$. At the end, $10 \mathrm{~mL}$ of ethanol:acetone:water $(1: 1: 1)$ and $10 \mathrm{~mL}$ of potassium hydroxide solution $(0.05 \mathrm{M})$ were added. Excess potassium hydroxide was titrated with HCI solution $(0.05 \mathrm{M})$ with blue bromothymol indicator $(1 \% \mathrm{~m} / \mathrm{v})$. The determination was calculated using the Equation 2, where the unit of activity (U) was defined as the necessary amount of enzyme for the release of $1 \mu \mathrm{mol}$ of fatty acid per minute, under the study conditions.

$$
A(U / g)=\frac{\left(V_{S}-V_{E}\right) *[H A] * 1000}{m * t}
$$

where $V_{S}$ is the volume $(\mathrm{mL})$ of acid titrated in standard Erlenmeyer, $\mathrm{V}_{\mathrm{E}}$ is the volume $(\mathrm{mL})$ in each experiment, HA the standardized concentration of the acid solution used (mol/L), $\mathrm{m}$ is the mass of biocatalyst used and $\mathrm{t}$ is the reaction time ( $\mathrm{min})$.

\section{RESULTS AND DISCUSSION}

\subsection{Synthesis of Magnetic Nanoparticles}

For the synthesis of maghemite, was used $250^{\circ} \mathrm{C}$ instead of $200^{\circ} \mathrm{C}$ to avoid the inversion of the maghemite structure in hematite, considering its minimum inversion temperature $\left(\mathrm{T}_{\text {inv }}\right)$ at $250^{\circ} \mathrm{C}$ (DUNLOP and ÖZDEMIR, 1997). Figure 3 shows the nanoparticles obtained at the end of the synthesis.

Thus, starting from $5.52 \mathrm{~g}$ of $\mathrm{FeCl}_{3}$ and $2.30 \mathrm{~g}$ of $\mathrm{FeCl}_{2}$ for magnetite synthesis, a mass of $4.56 \mathrm{~g}$ and $4.63 \mathrm{~g}$ was obtained, yield of $58.31 \%$ and $59.21 \%$ for synthesis using sodium hydroxide and ammonium hydroxide. The synthesis of maghemite, starting from $10.03 \mathrm{~g}$ of $\mathrm{FeCl}_{3}$, was obtained mass of $4.91 \mathrm{~g}$, yield of $49 \%$. During the synthesis of maghemite, the change in color of the solution from ferric chloride to dark red after the addition of sodium sulfite solution is justified by the formation of the complex $\left[\mathrm{Fe}_{2}\left(\mathrm{SO}_{3}\right)\right]^{4+}$, making the solution 
yellow with the total reduction of dissolved iron. In addition, the formation of nanoparticles by the addition of precipitating agents in both synthesis corresponds to iron oxidation, resulting in MH, MN1 and MN2 nanoparticles (PIMENTA, 2010).

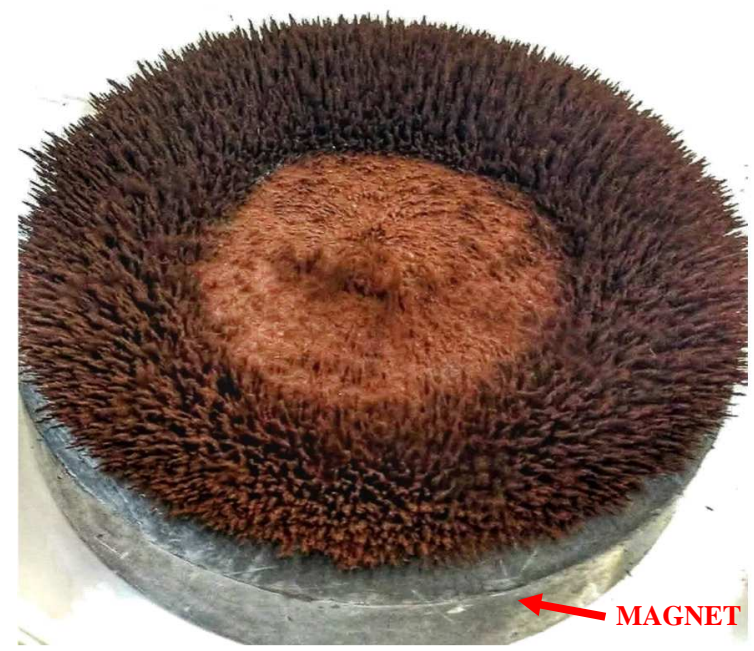

Figure 3. Magnetic nanoparticles obtained.

\subsection{Modified Nanoparticles}

The modification was performed in part of the nanoparticles for immobilization by covalent bond, being the activation process with APTES, a silane and amino groups carbonyls, increasing interaction between the enzyme and modified nanoparticles (LIANG et al., 2014; HAO et al., 2019;
Analyzing the Figure 4, it is possible to observe stretching regions $(v)$ of characteristic groups of the compounds used for the modification process, having the largest stretch in the region between the range $1200-900 \mathrm{~cm}^{-1}$, corresponding to the stretch of the carbonyl group (C-O: $\left.1100 \mathrm{~cm}^{-1}\right)$, in addition to the alkoxy and silane groups ( $\mathrm{Si}-\mathrm{O}-\mathrm{C}$ : between $1160-1070$ $\left.\mathrm{cm}^{-1}\right)$. Another region identified is for the stretching of the amino groups $\left(\mathrm{NH}_{2}\right.$ : between $\left.1650-1475 \mathrm{~cm}^{-1}\right)$ coupled during the activation of the support, as well as the stretching of iron oxide (Fe-O: $575 \mathrm{~cm}^{-1}$ ) (CASAGRANDE and REPETTE, 2018; PADILLA et al. 2011; PAVIA et al., 2010).

In this context, when compared to each other, it was found that the lower transmittance characteristic of the stretching of these groups was seen for the analysis of maghemite, showing the best grouping of compounds in relation to the other nanoparticles. However, as the purpose of the functionalization process is the bonding of these free groups with glutaraldehyde, the best for the efficiency in the process would be a small stretch band, showing the presence of few free groups (PAVIA et al., 2010). Thus, it is possible to conclude that the functionalization process was less efficient in the MN2 sample compared to the other samples analyzed.

\subsection{Physical Characterization of Immobilized Biocatalyst}

After the process of modification in part of the nanoparticles, the enzyme was immobilized by covalent bonding using the modified supports and by physical adsorption in the synthesized pure material. Then, the physical

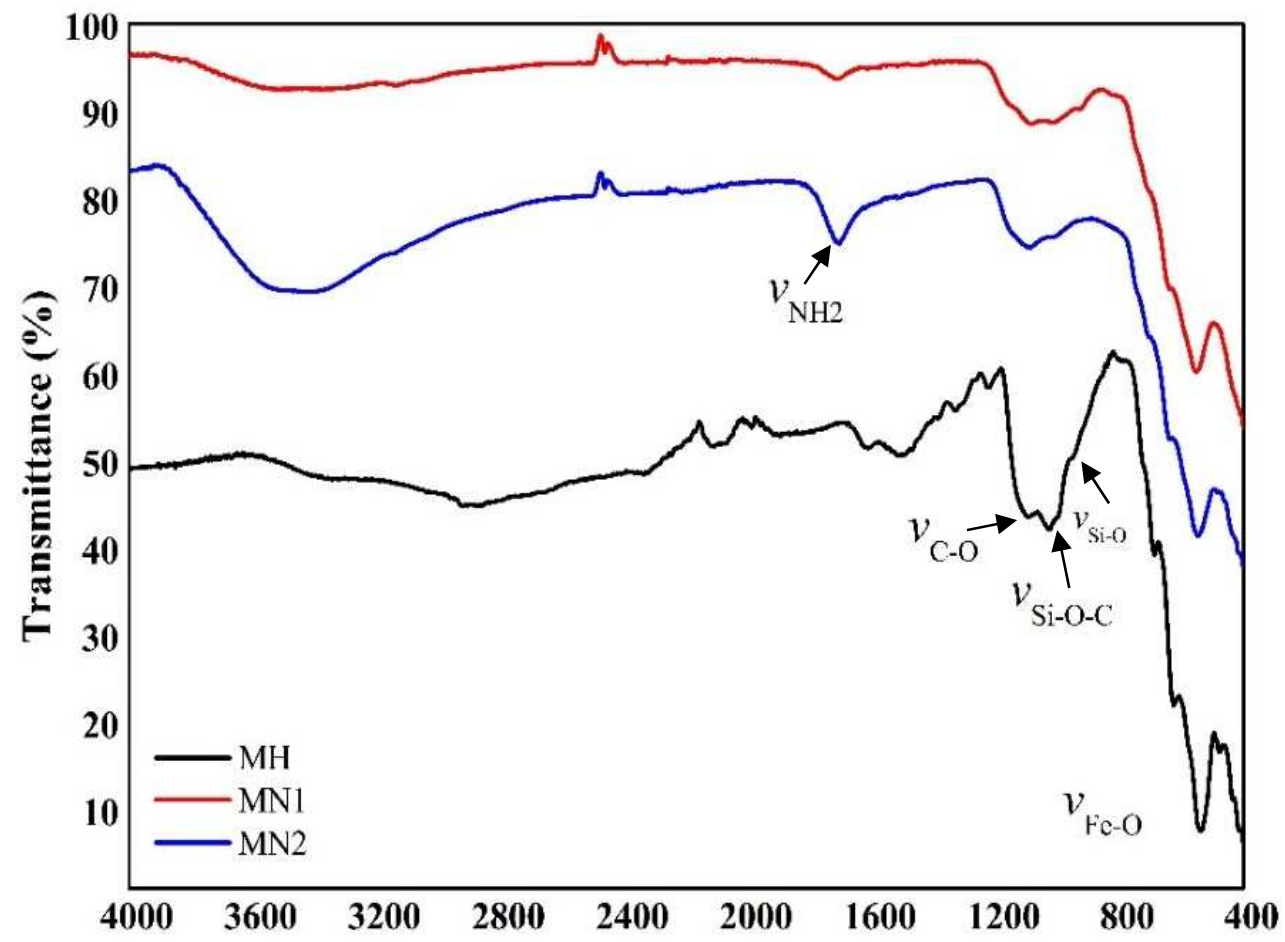

Figure 4. Infrared spectroscopy of modified samples of MN1, MN2 and MH.

PEREIRA, 2009; NELSON and COX, 2014). The infrared spectroscopy of the supports after the modification process is shown in Figure 4 coupler reagent, and functionalization with glutaraldehyde, promoting irreversible cross reactions and resulting in a difference of carbonyl electrons in the functional group. characterization of the biocatalyst immobilized by infrared spectroscopy was performed. The spectroscopies of the immobilized by physical adsorption (Figure 5) and by covalent bonding (Figure 6) are shown. 


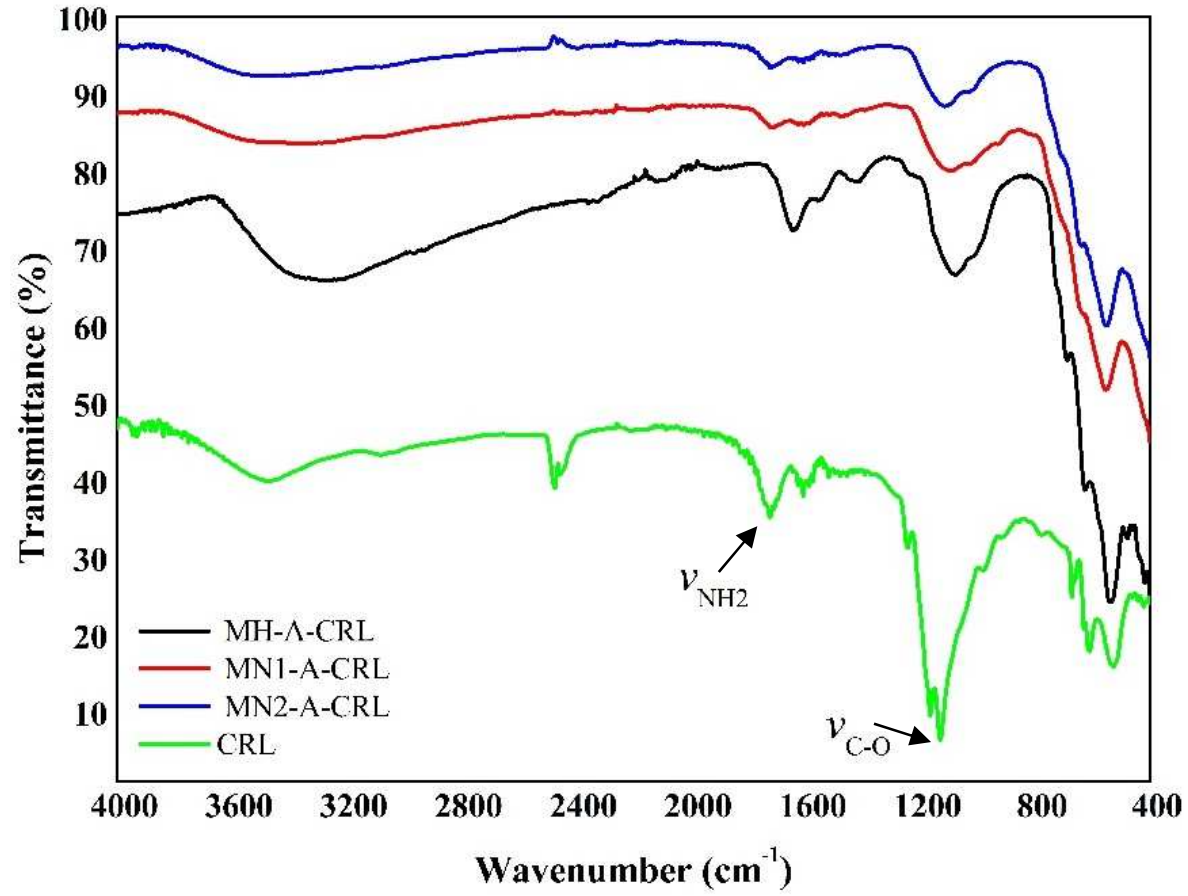

Figure 5. Infrared spectroscopy of biocatalysts immobilized by physical adsorption in samples MH-A-CRL, MN1-A-CRL and MN2-A-CRL.

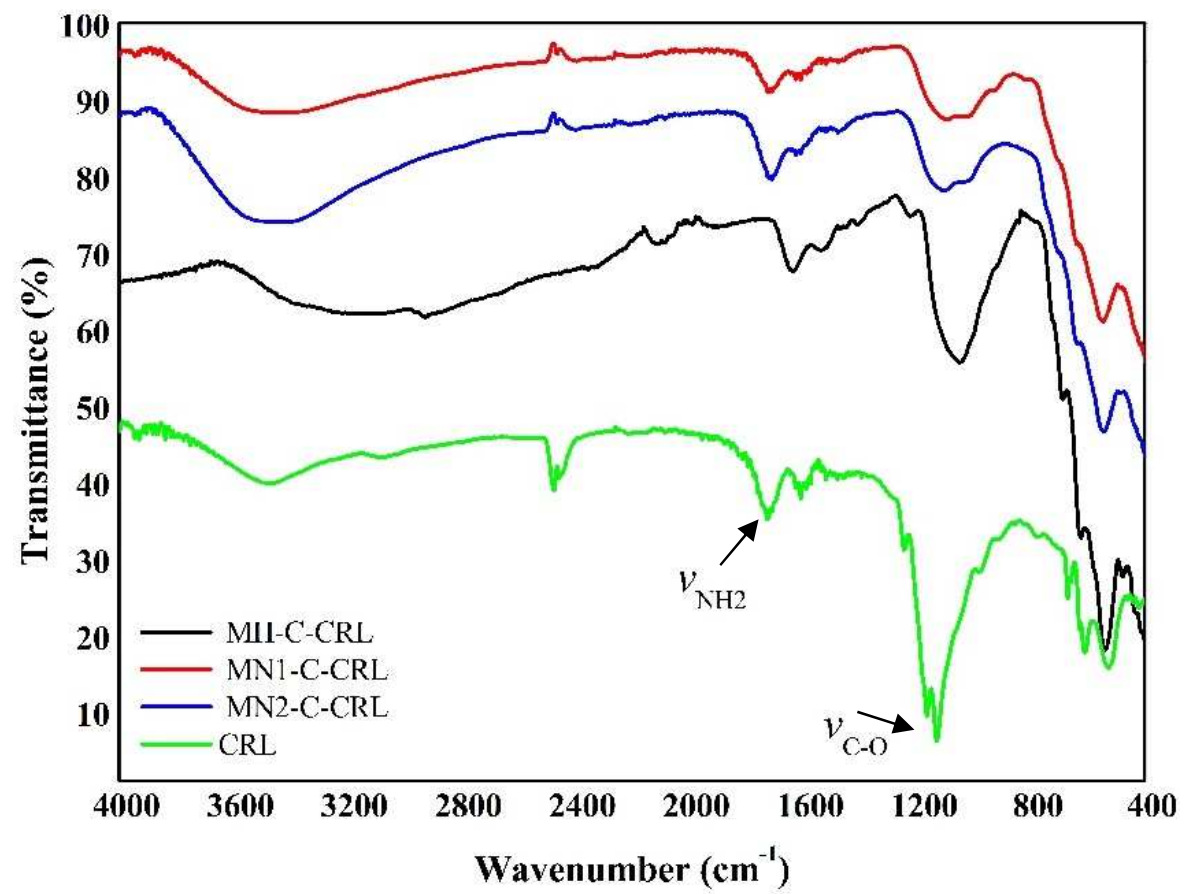

Figure 6. Infrared spectroscopy of biocatalysts immobilized by covalent bonding in samples MH-C-CRL, MN1-C-CRL and MN2-C-CRL

Based on the Figures 5 and 6 , it is possible to verify that when comparing the immobilization processes, the presence of regions with characteristic stretching of groups of lipase interest was higher for immobilization by covalent bonding. Comparing the immobilization processes separately, it was found that for both immobilization processes, maghemite was better than others supports for lipase immobilization due to the lower transmittance resulting from the analysis, since the lower the percentage of transmittance higher the absorbance of the compound in the analyzed material (PADILLA et al. 2011). In addition, to the infrared spectroscopy analysis, it was also carried the determination of the hydrolytic activity of biocatalysts resulting from both immobilization processes, in order to verify the best immobilization efficiency between the methods studied. 


\subsection{Hydrolytic Activity of Immobilized Biocatalysts}

The results obtained for the determination of the hydrolytic activity of biocatalysts immobilized by physical adsorption are shown in Table 1 and by covalent bonding in Table 2.

Table 1. Average Hydrolytic Activity (U/g) of biocatalysts immobilized by physical adsorption.

\begin{tabular}{cc} 
Samples & Hydrolytic Activity $($ U/g) \pm STDEV \\
MH-A-CRL & $126.37 \pm 19.66$ \\
MN1-A-CRL & $115.18 \pm 24.02$ \\
MN2-A-CRL & $121.87 \pm 12.77$ \\
\hline
\end{tabular}

Table 2. Average Hydrolytic Activity (U/g) of biocatalysts immobilized by covalent bonding.

\begin{tabular}{cc|} 
Samples & Hydrolytic Activity (U/g) \pm STDEV \\
MH-A-CRL & $167.27 \pm 12.93$ \\
MN1-A-CRL & $144.35 \pm 12.81$ \\
MN2-A-CRL & $144.89 \pm 12.05$ \\
\hline
\end{tabular}

Analyzing the results presented in the previous tables, it was identified that the values of hydrolytic activity obtained for the immobilized biocatalyst by covalent bonding were better than the results obtained by physical adsorption. The highest hydrolytic activity was obtained from the immobilization of lipase in maghemite, in both methods of immobilization, showing greater efficiency in the process when using this nanoparticle as magnetic support.

Comparing with other studies, Silva and Silva (2014) presented an activity of $1.389 \mathrm{U} / \mathrm{g}$ when POS-PVA was used for covalent bond immobilization. Hou et al. (2015) showed an activity of $119.43 \mathrm{U} / \mathrm{g}$ for the immobilization in magnetic shell of polydopamine/alginate by covalent bond. Jafarian et al. (2018) points out that, when immobilized in graphene oxide nanosheets by covalent bond, the activity obtained was 167.04 $\mathrm{U} / \mathrm{g}$.

The activity values obtained in the study of immobilization in magnetite and maghemite are closer to the values presented by the studies that used polydopamine/alginate magnetic shell and graphene oxide nanosheets. The small difference presented between the authors and the results obtained can be justified by the difference in the surface area, being greater in porous materials such as magnetic nanoparticles used in this study, being a better use of the structure for enzyme immobilization (BRÍGIDA, 2010). However, the great difference seen between the other activities presented can be justified by the process and support used for immobilization, since such a process can cause problems regarding the steric impediment of the substrate to the binding site (PAULA et al., 2008).

\section{CONCLUSION}

Studying the synthesis of magnetic nanoparticles of maghemite $(\mathrm{MH})$ and magnetite, synthesized with sodium hydroxide (MN1) and ammonium hydroxide (MN2), the highest yield obtained was $59.21 \%$ for the synthesis of $\mathrm{MN} 2$ nanoparticles. Analyzing the infrared spectroscopies, there was a greater stretch of lipase characteristic regions when immobilized in maghemite, in both methods of physical adsorption and covalent bonding. In addition, in relation to hydrolytic activity, better results were obtained when $\mathrm{MH}$ nanoparticles were used as immobilization support in both immobilization processes, with the highest activity of 174.67 U/g obtained for the immobilization of CRL in MH by covalent bond. Therefore, when the use of magnetic nanoparticles for the immobilization of Candida rugosa lipase was evaluated, a better performance was verified for the use of maghemite as an immobilization support.

\section{ACKNOWLEDGEMENTS}

Fundação de Amparo à Pesquisa do Estado de São Paulo (FAPESP) - Processes 2017/11482-7 and 2018/09904-3, Department of Engineering Bioprocesses and Biotechnology, School of Pharmaceutical Sciences, São Paulo State University (UNESP). Special thanks to Bárbara Fernandes Izidoro and João Vitor Bardasi Liba for the support and encouragement to research.

\section{REFERENCES}

BRÍGIDA, A. I. S. Imobilização de lipases utilizando fibra de coco verde como suporte para aplicações industriais. 2010. 220 f. Tese (Doutorado em Ciências) - Escola de Química, Universidade Federal do Rio de Janeiro, Rio de Janeiro, RJ, 2010.

CAMPESTRINI, E.; SILVA, V. T. M.; APPELT, M. D. Utilização de enzimas na alimentação animal. Revista Eletrônica Nutritime, v. 2, n. 6, p. 259-272, 2005.

CARVALHO, N. B.; LIMA, A. S.; SOARES, C. M. F. Uso de sílicas modificadas para imobilização de lipases. Química Nova, v. 38, n. 3, p. 399-409, 2015.

CASAGRANDE, C. A.; REPETTE, W. L. Monitoramento da hidrólise/condensação do tetraetoxisilano em solução com baixo teor alcoólico por análises de espectroscopia de infravermelho. Revista Matéria, v. 23, n. 4, 2018.

DUNLOP, D. J.; ÖZDEMIR, Ö. Rock Magnetism, Fundamentals and Frontiers, Cambridge University Press, 1997.

HAO, Y.; CHENA, Y.; XIA, H.; GAO, Q. Surface chemical functionalization of starch nanocrystals modified by 3aminopropyltriethoxysilane. International Journal of Biological Macromolecules, v. 126, p. 987-993, 2019.

HOU, C.; QI, Z.; ZHU, H. Preparation of core-shell magnetic polydopamine/alginate biocomposite for Candida rugosa lipase immobilization. Colloids and Surfaces B: Biointerfaces, v. 128, p. 544-551, 2015.

JAFARIAN, F.; BORDBAR, A. K.; ZARE, A.; KHOSROPOUR, A. The performance of immobilized Candida rugosa lipase on various surface modified graphene oxide nanosheets. International. International Journal of Biological Macromolecules, v. 111, p. 1166-1174, 2018.

JUNIOR, F. G. S.; MARINS, J. A.; RODRIGUES, C. H. M.; PINTO, J. C. A magnetic composite for cleaning of oil spills on water. Macromolecular Materials and Engineering, v. 295, n. 10, p. 942-948, 2010.

KUMAR, V.; JAHAN, F.; RAGHUWANSHI, S.; MAHAJAN, R. V.; SAXENA R. K. Immobilization of Rhizopus 
oryzae lipase on magnetic $\mathrm{Fe}_{3} \mathrm{O}_{4}$-chitosan beads and its potential in phenolic acids ester synthesis. Biotechnology and Bioprocess Engineering, v. 18, n. 4, p. 787-795, 2013.

LIANG, Y.; HUANG, J.; ZANG, P.; KIM, J.; HU, W. Molecular layer deposition of APTES on silicon nanowire biosensors: Surface characterization, stability and $\mathrm{pH}$ response. Applied Surface Science, v. 322, p. 202-208, 2014.

MIJONE, P. D. Imobilização de lipase em suporte magnetizado e aplicação na síntese de ésteres de etila em sistema descontínuo e contínuo. 86f. Dissertação (Mestrado na área de Processos Catalíticos e Biocatalíticos) do Programa de Pós-Graduação em Engenharia Química, Universidade de São Paulo, Lorena, SP, 2014.

NELSON, D. L.; COX, M. Lehninger - Princípios de Bioquímica. 6 ed., Porto Alegre: Artmed, 2014.

OLIVEIRA, L.C.A.; FABRIS, J.D.; PEREIRA, M.C. Óxidos de ferro e suas aplicações em processos catalíticos: uma revisão. Química nova, v. 36, n. 1, p. 123-130, 2013.

PADILLA, R. Y. C.; PENHA, J. M.; RICKS, A. T.; FRANCESCHI, E.; LIMA, A. S.; SILVA, D. P.; SOARES, C. M. F. Propriedades morfológicas e fisicoquímicas da lipase Candida rugosa imobilizada em poli(3-hidroxibutirato-co-hidroxivalerato). XVIII Simpósio Nacional de Bioprocessos (SINAFERM), 2011, Caxias do Sul, RS, 2011.

PAULA, A. V. de. Reestruturação da gordura de leite por interesterificação enzimática empregando lipase imobilizada: otimização das condições reacionais e operacionais. 2012. 202p. Tese (Doutorado em Biotecnologia Industrial na área de Microbiologia Aplicada) da Escola de Engenharia de Lorena, Universidade de São Paulo, Lorena, SP, 2012.

PAUlA, A. V.; MOREIRA, A. B. R.; BRAGA, L. P.; CASTRO, H. F.; BRUNO, L. M. Comparação do desempenho da lipase de Candida rugosa imobilizada em suporte híbrido de polissiloxano-polivinilálcool empregando diferentes metodologias. Química Nova, v. 31, n. 1, p. 35-40, 2008.

PAVIA, D. L.; LAMPMAN, G. M.; KRIZ, G. S.; VYVYAN, J. R. Introdução à Espectroscopia. Cengage Learning,
2010.

PEREIRA, A. V. P. Análise e caracterização de tecidos porcino e bovino fixados com glutaraldeído para aplicação em biopróteses cardíacas. 2009, 100f. Dissertação (Mestrado em Ciências e Engenharia de Materiais) da Universidade Federal de Minas, Belo Horizonte, MG, 2009.

PIMENTA, A. R. L. Nanopartículas Magnéticas para Nanomedicina 2010. 61f. Dissertação (Mestrado em Engenharia de Materiais) - Instituto Superior Técnico, Universidade Técnica de Lisboa, Lisboa, 2010.

PINTO, P. A. Imobilização de lipase em suporte magnetizado e aplicação na síntese de ésteres de etila em sistema descontínuo e contínuo. 2017. 70f. Monografia de Graduação em Engenharia Química - Escola de Engenharia de Lorena, Universidade de São Paulo, Lorena, SP, 2017.

REZANKA, T.; PÁDROVÁ, K.; SIGLER, K. Regioisomeric and enantiomeric analysis of triacylglycerols. Analytical Biochemistry, v. 524, p. 3-12, 2017.

SHELDON, R. A.; PELT, S. Enzyme immobilisation in biocatalysis: why, what and how. Chemical Society Reviews, v. 42, n. 15, p. 6223-6235, 2013.

SILVA, A. F., SILVA, E. M. Caracterização físico-química de lipase de Candida rugosa e avaliação da imobilização por ligação covalente em POS-PVA. $10^{\circ}$ Seminário de Iniciação científica da UFT, 2014, Palmas, TO, 2014.

TAN, T.; LU, J.K; NIE, K.L; DENG, L.; WANG, F. Biodiesel production with immobilized lipase: A review. Biotechnology Advances, v.28, p.628-634, 2010.

VESCOVI, V.; KOPPA, W.; GUISÁN, J. M.; GIORDANO, R. L. C.; MENDES, A. A.; TARDIOLI, P. W. Improved catalytic properties of Candida antarctica lipase B multiattached on tailor - made hydrophobic silica containing octyl and multifunctional amino-glutaraldehyde spacer arms. Process Biochemistry, v. 51, p. 2055-2066, 2016.

ZHENG, M.; WANG, S.; XIANG, X.; SHI, J.; HUANG, J.; DENG, Q.; HUANG, F.; XIAO, J. Facile preparation of magnetic carbon nanotubes-immobilized lipase for highly efficient synthesis of 1,3-dioleoyl-2palmitoylglycerol-rich human milk fat substitutes. Food Chemistry, v. 228, p. 476-483, 2017. 